\title{
Promotion Costs Analysis To Increased Volume Sales In The Convection Companies
}

\author{
Listiawati $^{1}$, Karta Negara Salam ${ }^{2 *}$, Retno Wulansari ${ }^{3}$, Pramudi Harsono ${ }^{4}$ \\ ${ }^{1,4}$ Bina Bangsa University, Indonesia \\ ${ }^{2}$ Nitro, Institute of Business and Finance, Indonesia \\ ${ }^{3}$ Pamulang University, Indonesia \\ ${ }^{*}$ Corresponding author: \\ Email: karnesproperty@gmail.com
}

\begin{abstract}
The purpose of this study is to obtain empirical data about whether or not there is a relationship between sales promotion costs and sales volume and how much influence the promotion costs have on sales volume at the company. In this study, the documentation method was used in data collection, then proceeded to the analysis process using correlation and regression analysis. The population in this study is the total cost of sales promotion and sales volume at the company. Due to the limitations of time, cost, manpower, and so on, the researchers took samples, namely sales promotion costs, and company sales volume, between 2018-2020.Based on the results of the analysis for three years, it was obtained that $r X Y=0.718$ with $N=36$ and a significant level of 0.000, obtained $r$ table $=0.708$. This shows $r x y>r$ table, which means that $r X Y$ is significant and Ha is accepted. Because Ha is accepted, there is a positive and significant relationship between Sales Promotion Costs and Sales volume at convection companies. Furthermore, the influence of Biya promotion on sales volume can be seen on the determinant coefficient $\left(R^{2)}\right.$ where it is mentioned in a row in 2018; 2019; and 2020 is 0.675; 0.554; and 0.507. this shows that the average annual promotion costs have an effect of more than $50 \%$ on the company's sales volume.
\end{abstract}

Keywords: Promotional Cost, Sales Volume

\section{INTRODUCTION}

In this era of corporate competition, the level of competition between companies is getting sharper. Competition is a problem that arises from outside the company where the competition will surface from other similar companies. One way to win the competition is to get as many consumers as possible by promoting the products produced by the company.A company is founded to achieve the expected goals, both short-term and long-term goals. One of the supporting factors in achieving this business is in the field of " promotional cost analysis ". Promotional costs are all expenses incurred for promotional purposes. Promotional costs are an element of financial statements, so if we want to analyze promotional costs, we must first examine the financial statements. Dissect the financial statements into their elements, examine each of these elements and examine the relationship between these elements to obtain a good and precise understanding and understanding of the report itself, so that we find the element of promotional costs and their relationship with other elements.

The company's ability to manage its finances can bring many benefits to the company. In spending the company must try to adjust to the needs without leaving the norms of trade. Technically, this can be achieved if the company can determine its marketing strategy by analyzing the activities in the marketing mix properly, namely analyzing products, prices, distribution channels, and promotions.Promotion is one of the areas of marketing activities that can generally be used by companies to increase their sales volume. This is done if the product distribution channel price has been determined correctly by the company, then the promotion will play a very important role.In carrying out production activities, the company requires a fairly large cost sacrifice. With large promotional costs, it is also expected that promotional activities will be wider in reaching consumers and can achieve a greater number of requests, the amount of sales volume is influenced by promotional factors, while the size of the promotion costs depends on the marketing party who 
does it.As a growing company, as a company engaged in the garment industry that produces trousers, we face many challenges.

These challenges can come from similar garment companies or other companies with more wellknown trademarks. Then the sale is effective in supporting the researchers took the title "promotion costs analysis to increased volume sales in the convection companies ".In carrying out production activities, the company requires a fairly large cost sacrifice. With large promotional costs, it is also expected that promotional activities will be wider in reaching consumers and can achieve a greater number of requests, the amount of sales volume is influenced by promotional factors, while the size of the promotion costs depends on the marketing party who does it. Based on existing conditions, companies that only use one type of promotional media in a year, this is more due to the company's assumption that minimizing promotional costs can reduce expenses, which means the profit from sales turnover is not reduced much for promotional costs.Based on the scope of the research above, the formulation of the problem proposed is 1) How does the cost of the promotion related to the volume of sales in PT. Pesona Remaja? 2) How much does the promotional cost affect the sales volume in PT. Pesona Remaja?

\section{Promotion}

Promotion is one of the company's marketing tools that aim to make the products marketed can be widely known by consumers with a wide range of promotions so that sales volume is expected to be further increased. While the effectiveness of the promotional tools carried out depends on the promotional media used and the type of product being marketed.The definition of promotion according to Tjiptono (2010:291) is a marketing activity that seeks to disseminate information, influence or persuade and increase the target market for the company and its products so that they are willing to accept, buy and deserve the products offered by the company concerned.

Private (2014:349) gives the understanding that promotion is a one-way flow of information or persuasion made to direct a person or organization to actions that create exchanges in marketing. The importance of promotion, in general, can be classified as: a) Efforts to modify consumer behavior to change behavior and opinions for purchasing company goods and services, b) Efforts to increase consumers to know there is a certain product in their market, c) Business to inform the target market in the product life cycle to increase primary demand, d) Efforts to persuade consumers to make a purchase and can have a long-term influence on buyer behavior.In developing promotional channels, the company can use one of the variables or a combination that is coordinated with a product, price, and distribution strategy. Together these variables form a marketing mix aimed at finding markets. There are four main tips in the promotion mix:

\section{Advertising}

According to Kotler and Armstrong (2009:111). Advertising is defined as a form of non-personal presentation and promotion of products that are paid for by a particular sponsor. The use of advertising as a component of the promotional mix provides advantages: 1) It can remind buyers, because there is a mix of writing or sound that can be heard, seen, or read at any time, 2) Forming a product motif that directs someone to buy the product, 3) Saving costs, because advertising can simultaneously reach many consumers. The disadvantages of advertising are a) It is inflexible because it has been formed and executed according to plan so it is difficult to resolve with consumer reactions, b) Advertising helps in introducing a product, but for its effectiveness, the advertisement must be repeated and this requires a large amount of money.c) Advertising does not immediately cause a reaction from consumers to buy but is a delayed reaction that occurs when the advertisement is repeated.

\section{Sales promotion}

Sales promotion is a promotional activity that excludes advertising, publicity, and personal selling. Companies use sales promotions to get stronger and faster responses. Sales promotion is more flexible because it can be done at any time at a relatively low cost compared to advertising and personal selling, it also encourages sluggish sales. 


\section{Publicity}

Publicity is any amount of information about goods or organizations that is disseminated to the public through the media free of charge or without the supervision of a sponsor. Besides that, publicity has three strengths, namely 1 ) the value of trust $\rightarrow$ Articles and news in the media are usually more authentic and more trusted by readers than advertisements, 2) Pushed out $\rightarrow$ Publicity can be reached by many parties who avoid salespeople, or advertising messages that reach buyers in the form of news and not direct sales communications, 3) Dramatization $\rightarrow$ Publicity has the potential to dramatize a company or product with other promotional variables, so promotional programs can be very effective.

\section{Personal selling}

Personal selling is intended as a promotion because personal selling can increase the number of sales through communication between the seller and prospective buyers. Personal selling is the most effective way of instilling buyer choice at a certain level in the buying process. Because when compared to advertising, personal selling has three special qualities, namely: 1) Dealing directly with potential buyers personally, 2) Familiarity, 3) Responsiveness.

\section{Promotion Purpose}

Every company in carrying out promotions certainly has a goal. In this regard, several things can be said to be the main goal in running a promotion. According to Sutisna (2001:53), that promotion is any form of communication used by companies (marketers) to inform (information) persuade or remind people about products, services, images, ideas, or community and company involved with the intention that people can accept it and do something about it. actions as desired by the company (marketing). The objectives of the promotion are: behavior modification; announcement, familiarity, bring to remind.

\section{Factors Affecting Promotion}

According to Asri (1991:144) four factors need to be considered to determine the form of promotion, these factors are 1) available funds; 2) Marketplace trait. Another consideration is the many types of potential buyers. A market with only one type of buyer requires a different promotional mix than a market with different types of buyers.

\section{Implementation and Promotion Cost}

Each stage of the implementation of this promotion plan can be carried out after the company determines and sets certain goals in its promotion. According to Irawan and Faried (1997:355) about the implementation of the promotion is to determine the objectives, identify the target market, prepare a budget, select news, determine the promotional mix; Companies can use different news themes in each of their promotional activities, for example, public relations can be done to create a positive impression of the company among buyers. Advertising can be focused on providing awareness to buyers about a product or company that offers.

Promotional costs are costs incurred by a company that aims to support the smooth running of promotions. The use of these promotional costs in general for each company varies depending on the size of the company, the area of marketing, and the type of product produced by the company concerned. According to Irawan and Faried (1997:161), there are three methods used in setting costs or promotion budgets, namely:

1) The method according to budget; This method completely ignores the impact of promotion on sales. There is no certainty in the preparation of the annual promotion budget so that it will be difficult to prepare long-term marketing plans.

2) The method based on a percentage of sales

The advantages of this method are:

a. With this method, promotion costs will vary according to the company's ability to sell its products

b. This method encourages management to think about the relationship between promotion costs, selling price, and unit profit

c. This method pushes the stability of competition to such an extent that competing companies will incur promotion costs with an approximately equal percentage of sales.

d. This method is relatively easy and simple 
The disadvantages of this method are:

a. This method allows setting available funding to be established rather than available opportunities.

b. This method doesn't look at the correlation or elasticity between sales and promotions

c. This method is based solely on past sales or what competitors are making

d. This method does not allow the preparation of a promotional budget by determining what products and areas should be provided with promotional costs.

3) Target method and task; In this method, the marketer must develop a promotional budget by setting specific goals, determining the tasks that must be carried out to achieve the goals, and estimating the costs to complete these tasks. The amount of this fee will constitute the proposed promotion budget.

\section{Sales Volume}

Sales are one of the marketing activities, while the definition of sales according to Private and Irawan (2012:40) declare "potential sales are the maximum level of sales that can be achieved by the company". In general, a company has a goal in sales activities, namely: achieving sales volume, earning profits, achieving market share

\section{Effect of Promotional Costs on Sales Volume}

The size of the company's sales volume is influenced by many factors. The factors are classified into two factors:

1. external factors; Namely, the size of the product sales volume is influenced by the environment outside the company, such as competition, people's memory of a product, economic, social, cultural, political, and government regulations.

2. internal factors; Namely, the size of product sales are influenced by the environment within the company itself. Overall these factors are the ability of the company's management itself, in other words, that the company's ability to manage its business and its effect on sales volume.

So, there is a close relationship between promotional costs and sales volume, where promotional costs are used by companies to approach potential customers, so they are moved to buy the products offered.

\section{Financial statements}

Companies need information in their management in both quantitative and qualitative forms. Financial statements are quantitative information that provides an overview of the state and financial position of a company. The writing of financial statements by the company must be following applicable standards, namely based on Financial Accounting Standards. Brigham (2001:36), argues that financial statements are "a few pieces of paper that are written with numbers, but it is also very important to think about the real assets behind the numbers.Financial reports according to Sudjaja and Barlian (2003:76) "A report that describes the results and accounting processes". Which is used as an information and communication tool between financial data or company activities and parties with an interest in these data or activities.

\section{Components of Financial Statements}

According to Munawir (2010:13) to analyze a financial report, one must have an understanding of the components of financial statements and the problems that may arise in the preparation of the report. The components of the financial statements and their elements are: Balance Sheet, Profit-Loss Statement, Cash Flow Statement.Financial statements are the final product or result of an accounting process.

1. Limitations of financial statements

In the financial statements, several limitations must be considered by all parties, namely; (Sofyan, 2018:201)

a) Financial statements are historical, containing reports on past events. Therefore, financial statements cannot be considered as reports on current conditions, so financial statements are not the only source of information in the economic decision-making process.

b) Financial statements are the value of the cost of goods or exchange value at the time of the transaction, not the current price.

c) Financial statements are general and are not intended to meet the needs of certain parties. 
d) The process of depreciation of financial statements does not escape the use of estimates and various available options that are both justified but cause differences in profit and asset figures.

e) Accounting does not include material information. Similarly, the application of accounting principles to a particular fact or item may not be carried out if this does not have a material effect on the feasibility of the financial statements.

f) Financial statements are conservative in the face of uncertainty; If there are several possible uncertain conclusions regarding the valuation of an item, the alternative that produces the lowest net income or asset value is usually chosen.

g) Financial statements are prepared using technical terms, and users of the reports are assumed to understand the technical language of accounting and the nature of the information reported.

h) Accounting is dominated by quantitative information. Information that is qualitative and facts that are not quantified are generally ignored. However, quantitative information can be a description or indication of qualitative information.

i) Changes in the energy purchased with money are evident but these are not reflected in the financial statements.

2. Financial statement analysis

Financial statement analysis is a process to dissect financial statements into their elements, examine each of these elements and examine the relationship between these elements to obtain a good and appropriate understanding and understanding of the report itself. The information generated from the process is expected to be able to deepen the information from the company's financial statements itself so that it is more useful for decision-makers. The steps in conducting financial analysis are: Reviewing data and reports, calculating, comparing, or measuring. There are two ways to compare the company's financial ratios, namely the "CrossSectional Approach" and "Time Series Analysis". Cross-Sectional Approach is a way of evaluating by comparing the ratios between one company and other similar companies at the same time. While Time Series Analysis is done by comparing the results achieved by the company from one period to another.

\section{METHOD}

\section{Research Types and Approach}

Based on the nature of the problem and research objectives, the research design used was descriptive correlational research. This method is used to describe, record, analyze, and interpret data from the variable cost of sales promotion sales turnover. So, it can be concluded that this research design is used to describe the relationship between the variable $(\mathrm{X})$ of sales promotion costs as the independent variable and sales turnover $(\mathrm{Y})$ as the dependent variable.

The relationship between the independent variable $(\mathrm{X})$ and the dependent variable $(\mathrm{Y})$, namely: The relationship between sales promotion costs and sales turnover.

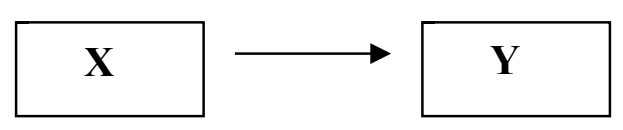

Information :

$\mathrm{X}$ : Independent variable (cost of sales promotion)

$\mathrm{Y}$ : Dependent variable (sales turnover)

\section{Population, Sample, and Data Collection Techniques}

According to Arikunto (2010:115) what is meant by population is "all research subjects. While the sample is "Part or representative of the population studied". The population in this study is the cost of sales promotion and sales turnover obtained by the convection company. While the samples taken are promotional costs and the amount of company sales turnover, during 2018-2020.In this study, the data collection techniques used were documentation techniques, and interview techniques as support. The documentation technique is carried out by collecting data and company archives regarding the list of sales promotion costs during 2018-2020 at convection companies. 


\section{Data analysis}

Data analysis is the most important part of the scientific method. Because by analyzing the data, it can be interpreted and give meaning that is useful in solving research problems.

1. Data Analysis Prerequisite Test

The technique used in this study is to use a linear regression formula or simple regression. For the data obtained to be analyzed, the data must be normal. For this reason, a normality test was carried out. The data is said to be normal if the data spread around the diagonal line and follows the direction of the diagonal line.

2. Correlation Analysis

In the activity of statistical data used to find the relationship between the variables. This technique is used to determine the relationship between sales promotion costs and sales turnover at the company's convection company.

$$
r_{x y}=\frac{N \sum x y-\left(\sum x\right)\left(\sum y\right)}{\sqrt{\left\{N \sum x^{2}-\left(\sum x\right)^{2}\right\}\left(N \sum y^{2}-\left(\sum y\right)^{2}\right\}}}
$$

Information:

$\mathrm{r}_{\mathrm{xy}}=$ Correlation coefficient $\mathrm{X}$ and $\mathrm{Y}$

$\mathrm{X}=$ Sales promotion cost variable biaya

$\mathrm{x}$ year 1 is the cost of distributing the flyer

$x$ 2nd year is cheap to market cost

$\mathrm{x} 3$ rd year is radio advertising cost

$\mathrm{y}=$ Sales turnover variable

$\mathrm{N}=$ Notation (number of subjects studied)

3. Simple Linear Regression Analysis

This analysis was conducted to determine the effect of the independent variable $(x)$ on the dependent variable (y). The value of the coefficient $\mathrm{X}$ of the promotion variable on the $\mathrm{Y}$ variable of sales volume obtained from simple linear regression obtained the regression equation for the $\mathrm{X}$ variable of the promotion variable on the $\mathrm{Y}$ variable of sales volume with promotions carried out by the company.

Regression analysis criteria

a) T-test with criteria

Criteria for decision-making on this test is to compare the value of $t_{\text {arithmetic }}$ and $t_{\text {table, }}$, if the value of $f_{t}$ is greater than $t$ table then the initial hypothesis $\left(\mathrm{H}_{\mathrm{o}}\right.$ is rejected and the alternative hypothesis $(\mathrm{Ha})$ is accepted, and vice versa.

b) Coefficient of Determination $\left(\mathrm{R}^{2}\right)$

Shows the magnitude of the contribution of the independent variable in explaining the dependent variable, so the value of the coefficient of determination $\mathrm{R}^{2}=$ a means that the promotion of the distribution of pamphlets contributes $\mathrm{a} \%$ to changes in the increase in sales volume while the remaining $\mathrm{b} \%$ is influenced by other variables not included in the study.

\section{RESULTS AND DISCUSSION}

\section{Production and Production Results}

The production process referred to here is the process of processing raw materials in the form of sheets of cloth into trousers. The production process that occurs is a continuous order production process (continuous). Raw materials are processed sequentially from one section to the next. This production process is usually carried out for mass production or large-scale production.At first, companies must go through a negotiation period, namely the period in which the company makes samples (production samples) and sends them to the customer. After the production sample is following the customer or has been approved by the customer, the production process for the product according to the order will begin, which includes the following processes: 
1. Cutting fabrics according to the type, size, and model according to the product sample.

2. Then after being cut, it begins to enter the sewing line, the first is the process of scraping the pieces of cloth.

3. After that, it enters the sewing process and in this sewing process, there are many sewing parts, which are carried out by each employee. So that each employee has their work specialization

4. After being sewn as a whole, it enters the treeming section which covers the entire stitching section.

5. After tidying up the next is the Quality Control section which controls the quality of the product which includes the model of the neatness of the stitches.

6. Then in the last section is the product ironing section which irons the products before they are included in the finishing section.

7. Then the last is the finishing section which includes packing and shipping.

\section{Production result}

The production result of the Company's Convection Company is in the form of jeans trousers with various patterns and certain sizes. The production results include: Women's Jeans, Men's Jeans, Jackets.

\section{Production and Marketing Costs}

Production costs are all costs incurred in connection with the processing of raw materials into finished goods. Production costs used by Convection companies consist of:

a. Raw Material Costs; Namely all costs incurred for the purchase of raw materials.

b. Direct labor costs; That is all costs incurred for the services of employees directly in the field of production.

c. Factory Overhead Costs; Namely production costs other than raw material costs and direct labor costs consisting of: penciling material costs, maintenance costs, repair costs, equipment costs, depreciation costs, insurance costs, electricity, water, telephone costs.

\section{Data analysis}

The data obtained to determine the cost of promotion and sales volume that has been achieved by the convection company are presented in table 1; table 2; and table 3

Table 1.Promotional Costs and Sales Turnover in 2018 Convection Company Company

\begin{tabular}{|l|l|c|c|}
\hline Year & \multicolumn{1}{|c|}{ Month } & Promotion Fee (X) & Sales Turnover (Y) \\
\hline \multirow{5}{*}{2018} & January & $1.760 .000,00$ & $304.042 .700,00$ \\
\cline { 2 - 4 } & February & $1.862 .000,00$ & $319.735 .180,00$ \\
\cline { 2 - 4 } & March & $1.930 .000,00$ & $321.654 .060,00$ \\
\cline { 2 - 4 } & April & $2.036 .000,00$ & $341.167 .950,00$ \\
\cline { 2 - 4 } & May & $1.980 .000,00$ & $304.038500,00$ \\
\cline { 2 - 4 } & June & $1.865 .000,00$ & $308.352 .000,00$ \\
\cline { 2 - 4 } & July & $1.989 .000,00$ & $320.678 .360,00$ \\
\cline { 2 - 4 } & August & $2.132 .000,00$ & $394.380 .800,00$ \\
\cline { 2 - 4 } & September & $2.080 .000,00$ & $32.908 .800,00$ \\
\cline { 2 - 4 } & October & $1.986 .000,00$ & $317.426 .900,00$ \\
\cline { 2 - 4 } & November & $1.870 .000,00$ & $3.902 .480 .030,00$ \\
\cline { 2 - 4 } & December & $1.810 .000,00$ & \\
\hline amount & & $23.300 .000,00$ & \\
\hline
\end{tabular}

Data source: processed, 2021

Table 2.Promotional Costs and 2019 Sales Turnover Company Convection Company

\begin{tabular}{|c|l|c|c|}
\hline Year & \multicolumn{1}{|c|}{ Month } & Promotion Fee (X) & Sales Turnover (Y) \\
\hline \multirow{6}{*}{2019} & January & $1.898 .000,00$ & $305.127 .020,00$ \\
\cline { 2 - 4 } & February & $1.980 .000,00$ & $316.503 .480,00$ \\
\cline { 2 - 4 } & March & $1.965 .000,00$ & $311.939 .238,00$ \\
\cline { 2 - 4 } & April & $2.013 .000,00$ & $342.714 .848,00$ \\
\cline { 2 - 4 } & May & $2.230 .000,00$ & $355.755 .150,00$ \\
\cline { 2 - 4 } & June & $2.150 .000,00$ & $312.244 .136,00$ \\
\cline { 2 - 4 } & July & $1.986 .000,00$ & $321.467 .270,00$ \\
\hline
\end{tabular}




\begin{tabular}{|l|l|c|c|}
\hline & August & $2.060 .000,00$ & $316.601 .770,00$ \\
\cline { 2 - 4 } & September & $2.130 .000,00$ & $360.561 .510,00$ \\
\cline { 2 - 4 } & October & $1.867 .000,00$ & $301.759 .530,00$ \\
\cline { 2 - 4 } & November & $1.986 .000,00$ & $325.020 .400,00$ \\
\cline { 2 - 4 } & December & $2.200 .000,00$ & $362.025 .906,00$ \\
\hline \multirow{2}{*}{ amount } & $24.465 .000,00$ & $3.931 .720 .258,00$ \\
\hline
\end{tabular}

Data source: Processed 2021

Table 3.Promotional Costs and Sales Turnover in 2020 Convection Company Company

\begin{tabular}{|l|l|c|c|}
\hline \multicolumn{1}{|c|}{ Year } & \multicolumn{1}{|c|}{ Month } & Promotion Fee $(\mathrm{X})$ & Sales Turnover $(\mathrm{Y})$ \\
\hline \multirow{6}{*}{2020} & January & $1.905 .000,00$ & $323.696 .500,00$ \\
\cline { 2 - 4 } & February & $2.020 .000,00$ & $325.853 .700,00$ \\
\cline { 2 - 4 } & March & $2.050 .000,00$ & $325.389 .550,00$ \\
\cline { 2 - 4 } & April & $2.123 .000,00$ & $319.378 .050,00$ \\
\cline { 2 - 4 } & May & $1.957 .000,00$ & $312.063 .600,00$ \\
\cline { 2 - 4 } & June & $2.058 .000,00$ & $318.357 .000,00$ \\
\cline { 2 - 4 } & July & $2.134 .000,00$ & $341.703 .050,00$ \\
\cline { 2 - 4 } & August & $2.200 .000,00$ & $349.064 .000,00$ \\
\cline { 2 - 4 } & September & $2.160 .000,00$ & $325.387 .550,00$ \\
\cline { 2 - 4 } & October & $2.178 .000,00$ & $337.373 .750,00$ \\
\cline { 2 - 4 } & November & $2.180 .000,00$ & $371.810 .550,00$ \\
\cline { 2 - 4 } & December & $2.276 .000,00$ & $3.978 .900 .900,00$ \\
\hline amount & & $25.241 .000,00$ & \multicolumn{2}{|c}{} \\
\hline
\end{tabular}

Data source: Processed, 2021

\section{Description of Sales Promotion Costs at the Company}

According to Tjiptono (2010:291) promotion is a marketing activity that seeks to disseminate information, influence or persuade and increase the target market for the company and its products so that they are willing to accept, buy and deserve the products offered by the company concerned. Promotional activities are activities that have a major role in introducing a product to the final consumer. The funds needed for promotional activities are quite large. Regardless of the issue of how the best form of the promotional mix, the real determining factor is the number of funds provided for promotional purposes. A company with sufficient funds can make a sales promotion program more effective than a company with limited funding sources.

Promotional expenditure used by the Company has increased from year after year. The description of the data indicates that the Company wants to introduce and promote its products optimally and always increases from year after year. Promotional costs incurred by the Company are used for promotional activities in the form of sales promotion, in this promotional activity, the company promotes products from the Company to retailers or agents directly by its sales. This type of promotion is included in the sales force promotion, Tjiptono (2010:229) argues that the sales force is a "sales promotion that aims to encourage or motivate the sales force.The company emphasizes promotions by using salespeople. Because the characteristics of the products being marketed are products that are the primary needs of consumers, namely clothing (clothing), so product sales are highly dependent on the performance of the sales force.

\section{Description of Sales Turnover in the Company}

Basically, the company wants a high sales turnover, this is done to encourage an increase in sales profit. In general, a company has a goal in sales activities, namely: achieving sales volume, earning profits, and achieving market share. This goal can be realized if the sale can be carried out following the company's plan. This is intended to continue how much the company's ability to serve or fill consumer needs.

The Relationship and Promotional Influence Over The Turnover Sales In The Company

Sales are greatly influenced by how marketing management manages its marketing mix. This means that sales are influenced by the product with aspects offered by the company's strategy and pricing policy set by the company, distribution strategy, and policy set by the company, strategy and promotion policy by the company. 
The seller in buying and selling should be honest, forthright, and tell the truth, so don't lie and don't swore a lie, because a lying oath takes away the blessing of buying and selling. honest in the sense of saying or offer goods under the condition of the goods being traded, in addition, if offering goods, keep the merchandise away from decorations whose purpose is to deceive the buyer in the sense that the merchandise is decorated in such a way as to prevent defects in goods from being seen or disguised. Because this study uses correlation and regression analysis, what is known is the relationship between promotional costs and sales turnover and how much influence the promotion costs have on sales volume.This study shows that promotional costs are related and have a strong influence on sales volume. This is evidenced by the correlation coefficient of product-moment $\left(\mathrm{r}_{\text {count }}\right)$ is 0.718 , which is much greater than the critical price of $r$ product-moment $\left(\mathrm{r}_{\text {table }}\right)$ is 0.708 .

Because the product-moment correlation coefficient ( $r$ count $)$ is higher than the critical value of $r$ product-moment ( $\mathrm{r}$ table $)$, and its significance $(0.000)$ is less than 0.05 . and at the price of the determinant coefficient each year an average of more than $50 \%$ which affects sales volume is the cost of promotion.So, it can be said that the higher the promotional costs incurred by the company, the higher the sales turnover obtained. So that promotion costs are related and have a very strong influence on sales turnover. It can be seen that promotional activities are very supportive of the Company in increasing sales turnover because with promotional activities the Company can introduce its products to consumers at the retail level and end consumers. Although the costs incurred by the Company for promotional activities, the results obtained from these activities can result in a significant increase. After describing the results of research on the Company's Convection Company, the next step is to conduct a discussion of the problem which aims to determine the effect of promotions carried out on increasing the company's sales volume. To find out more about this, it can be seen from statistical analysis by using simple correlation analysis methods and regression analysis.With the increase in promotional costs, it can increase sales volume. To find out more about it, it can be seen from statistical analysis by using Correlation Analysis and Regression Analysis and by using ttest arithmetic.

a. Correlation analysis

Testing the hypothesis about a close relationship between promotion costs and sales turnover is by comparing the product-moment correlation coefficient ( $\mathrm{r}$ XY) with the critical price of $\mathrm{r}$ product-moment $(\mathrm{r}$ table). From the results of the analysis (SPSS) as shown in the attachment, the product-moment correlation coefficient (r XY) in 2018 is obtained; 2019; and 2020 is 0.839 ; 0.771 ; and 0.743 while the critical value of $r$ product-moment $\left(\mathrm{r}_{\text {table }}\right)$ is 0.708 . Because the product-moment correlation coefficient ( $\mathrm{r} \mathrm{XY}$ ) is higher than the critical value of $r$ product-moment ( $\mathrm{r}_{\text {table }}$ ), and its significance $(0.000)$ is less than 0.05 . it can be concluded reject Ho or it can be interpreted that Promotional Costs affect sales volume. Or the two have a very strong relationship.So, it is said that in the close positive relationship between promotional costs and sales volume there is a significant (significant) relationship.In theory, the size of the company's sales volume is influenced by internal and external factors of the company where promotion costs are the costs of activities carried out by the company to relate (market their products) to the wider community. Promotional costs must consider the relationship with the availability of company funds so that the selection of promotional media facilities will determine the emphasis on the company's operating costs.

b. Simple Linear Regression Analysis

This analysis was conducted to determine the effect of the independent variable $(x)$ on the dependent variable (y). The value of the coefficient $\mathrm{X}$ of the promotion variable on the $\mathrm{Y}$ variable of sales volume obtained from simple linear regression obtained the regression equation for the $\mathrm{X}$ variable of the promotion variable on the $\mathrm{Y}$ variable of sales volume with promotions carried out by the company.

Table 1.Recapitulation of regression test and correlation of promotion cost and sales volume.

\begin{tabular}{|c|c|c|c|}
\hline Year & Correlation coefficient & T Test Count & Determination $\left(\mathbf{R}^{\mathbf{2}}\right)$ \\
\hline $\mathbf{2 0 1 8}$ & 0,839 & 4,884 & 0,675 \\
\hline $\mathbf{2 0 1 9}$ & 0,771 & 3,832 & 0,554 \\
\hline $\mathbf{2 0 2 0}$ & 0,743 & 3,507 & 0,507 \\
\hline
\end{tabular}

http://ijstm.inarah.co.id 


\section{CONCLUSION}

Based on the description and discussion above in previous chapters, it can be concluded as follows:

1. The Company's sales promotion expenses have increased from year to year. This is evidenced that in 2018 the promotional costs issued by the company amounted to Rp. 23,300,000 with an average monthly expenditure of Rp. 1,941,667; while in 2019 the cost of sales promotion issued by the company was Rp. 24,465,000 with an average monthly expenditure of Rp. 2,038,750; while in 2020 the company's promotional costs were Rp. 25,241,000 with an average monthly expenditure of Rp. 2,103,417; this proves that the size of the promotion cost has a strong relationship with sales volume. This is evidenced by the product-moment correlation coefficient ( $\mathrm{r}$ count) in $2018 / 2019 / 2020$ is $0.839 / 0.771 / 0.743$, which is much higher than the critical price of $r$ product-moment ( $\mathrm{r}_{\text {table }}$ ) which is 0.708 . Because the product-moment correlation coefficient $(r$ count $)$ is higher than the critical value of $r$ product-moment $\left(r_{\text {table }}\right)$, and its significance $(0.000)$ is less than 0.05 .

2. In 2018 the sales turnover generated by the Company was Rp. 3,902,779,330 with an average monthly income of $\mathrm{Rp}$. 325,231,610,8; based on the coefficient of determination $\left(\mathrm{R}^{2}\right)$ in 2018 was $67.5 \%$ of Rp.325.231.610,8 (average revenue per month) affected the cost of sale, as well as in 2019 the sales turnover generated by the Company amounted to Rp.3.931.720.258 an average of Rp.327,643,354.8 monthly income $55.4 \%$ influenced by promotional costs, in 2020 the sales turnover generated by the Company was Rp.3.978,900,900 with an average monthly income of Rp.331,575,075; there is the effect of promotion costs by $50.7 \%$. So sales promotion costs have a strong influence on the company's sales turnover.

\section{REFERENCE}

[1] Arikunto, Suharsimi. 2010. Research Procedure: A Practical Approach. Jakarta: Rineka Cipta.

[2] Asri, Marwan. 1991. Marketing, First Printing. Yogyakarta: BPFE.

[3] Private Basu. 2014. Marketing Principles. Yogyakarta: Liberty.

[4] Basu Swastha, Dharmesta and Irawan, 2012, Modern Marketing Management. Jakarta: Gramedia

[4] Brigham, Thomas. E, (2001), Fundamentals of Financial Management, Volume I Edition IX, Earlangga, Jakarta.

[5] Irawan \& Faried Widjaya. 1997. Marketing 2000, First Edition. Yogyakarta: BPFE.

[6] Kotler, Philip. 2009. Marketing Management, Volume 1. Thirteenth Edition, Bob Sabran's Translation. Jakarta: Erlangga.

[7] Munawir, 2010, Analysis of Financial Statements, Fifteenth Printing,Yogyakarta: Liberty

[8] Sofyan, S Harahap, 2018, Critical analysis of financial statements, PT. Raja Grafindo persada, Jakarta.

[9] Sutisna. 2001. Consumer Behavior and Marketing Communications. Bandung: PT. Rosdakarya Youth.

[10] Tjiptono, Fandy. 2010. Marketing Strategy. Yogyakarta: Andy Offset 